\title{
Identifying Climate Change Signals from Downscaled Temperature Data in Umuahia Metropolis, Abia State, Nigeria
}

Ozabor $\mathrm{F}^{1}$ and Nwagbara $\mathrm{MO}^{2^{*}}$

${ }^{1}$ Department of Geography and Environmental Management, University of Port-Harcourt, Choba, Rivers State, Nigeria

${ }^{2}$ Department of Soil Science and Meteorology, Michael Okpara University of Agriculture, Umudike, Abia State, Nigeria

"Corresponding author: Nwagbara MO, Department of Soil Science and Meteorology, Michael Okpara University of Agriculture, Umudike, Abia State, Nigeria, Tel: 8023510554; Fax: 8023510554; E-mail: monwagbara@yahoo.com

Received Date: October 31, 2017; Accepted Date: January 09, 2018; Published Date: January 12, 2018

Copyright: (C 2018 Ozabor F, et al. This is an open-access article distributed under the terms of the Creative Commons Attribution License, which permits unrestricted use, distribution, and reproduction in any medium, provided the original author and source are credited.

\begin{abstract}
This study was about Identifying climate change, by adopting the downscaling techniques in Umuahia metropolis. The study adopted ex-post-facto research design and data for maximum and minimum temperatures were collected from the archive of NIMET and for the period 1986-2015. On the other hand large scale predictor's data were collected from the archive of HadCM3 for these periods 1960-2001 (NCEP) and 1960-2099(HadGCM3). Analyses were done using SDSM, ANOVA, PPMC and MLR. The study unraveled that, Mean sea level pressure (MSLP), Relative humidity at 500-hpa (r500), Relative humidity at 850-hpa ( 850$)$, and Temperature at 2 meters above sea level (temp) are the predictors of minimum and maximum temperature in the area. This also showed statistical significance at $\mathrm{P}<0.05$. During validation the monthly sub-model performed better by using these indices for minimum and maximum temperatures respectively R20.85 \& 0.70; RMSE $2.14 \& 2.72$; Rs $0.88 \& 0.56$; Value $0.00 \&$ 0.00 . Conversely, minimum and maximum temperature showed temporal variation for the period $1960-2080$ at $P<0.05(F, 284.1) \& p<0.05(F, 227.1)$ respectively, therefore indicating significant change in temperature characteristics. The study strongly advocate assembling a working group that will work on a regional downscaling project, forging a synergy between Nigerian meteorological agency and the working group, producing a localized GCM, and the need to carry out similar study across the other regions of Nigeria.
\end{abstract}

Keywords: Climate change; Signals; Downscaling; Models; Normal

\section{Introduction}

Climate is expressed as weather elements' characteristics observed and documented for a period of 30-35 years [1]. Therefore any change observed in a normal in comparison with the previous normal is termed climate change [2-9]. However, Ayoade [10,11], has argued that, to adequately affirm that, there is change in climate, the best practice is to compare results from three or more normal. This is because the change between two normal may just be 'noise. Thus to be able to explain climate change, the intergovernmental panel on climate change has always encouraged the building of General Circulation Models (GCMs) [12]. This is so because it has been verified [12-17] to be an adequate means of explaining climate change issues and forecasting [18] the likelihood of change in climate, and what effects climate change is going to have at regional and global scales [16]. However, the scales at which the GCMs are built are so large, thus the need to perform downscaling $[19,20]$.

Downscaling has emerged as a means (in climatological studies) of resolving what is known at a larger scale to what is obtainable at the local or even point scale [5-8,9,20-22]. It is usual to carry out downscaling using either or both of the following techniques: dynamic and statistical downscaling [18] although this study utilized statistical downscaling. Nevertheless, whether or not the resolution of the various GCMs is improved on, there will still be need to downscale [21]. This is because of the following advantages that the downscaling technique possess: it links the large scale predictors with the predict and (s); identifies the major controls of weather parameters; reproduces the predictand(s) datum or data with high precision; identifies scenario based weather information of the area for which downscaling investigation is carried out $[12,20]$.

All the same, in the developed world historical data of weather parameters are largely available [1] for climate explanation. While in the developing world the case is not the same [10] as station density is relatively sparse [10] incidences of wars, poor training of weather observer, period of weather station establishment etc. all of which affects weather data stock available. As such, identifying historical characteristics of weather for several places in the developing world is almost impossible. This is the case in Umuahia. Weather, data recording, started in the weather station in 1977, thus, trying to identify climate change from such data situation is difficult or spurious. Downscaling techniques therefore offers a scientific solution to this lacuna. This study therefore, sets out to unravel signals of climate change from downscaled data of Umuahia in Abia state.

\section{Materials and Methods}

\section{Study area}

Umuahia is capital of Abia State, South-eastern Nigeria, and has been growing in leaps and bounds since becoming state capital on August 27, 1991. The influx of civil and public servants, traders and contractors with the new status brought about rapid population growth and urbanization of the town. The area is a typical humid tropical area with its location at the intercept of latitude $05029^{\prime} \mathrm{N}$ and longitude $7033^{\prime} \mathrm{E}$, and altitude, at the highest point of about $205 \mathrm{~m}$ (Figure 1). Annual rainfall totals vary from about $1900 \mathrm{~mm}$ to $2400 \mathrm{~mm}$. This 
rainfall is of the double maxima type with peaks in the months of July and September. In recent times, September has being the month with highest amount of rainfall as against July whereas December has lowest amount (NRCRI, 2016). Air temperature ranges between $21^{\circ} \mathrm{C}$ and $34^{\circ} \mathrm{C}$, and relative humidity of $60 \%$ to $83 \%$ (NRCRI, 2016).

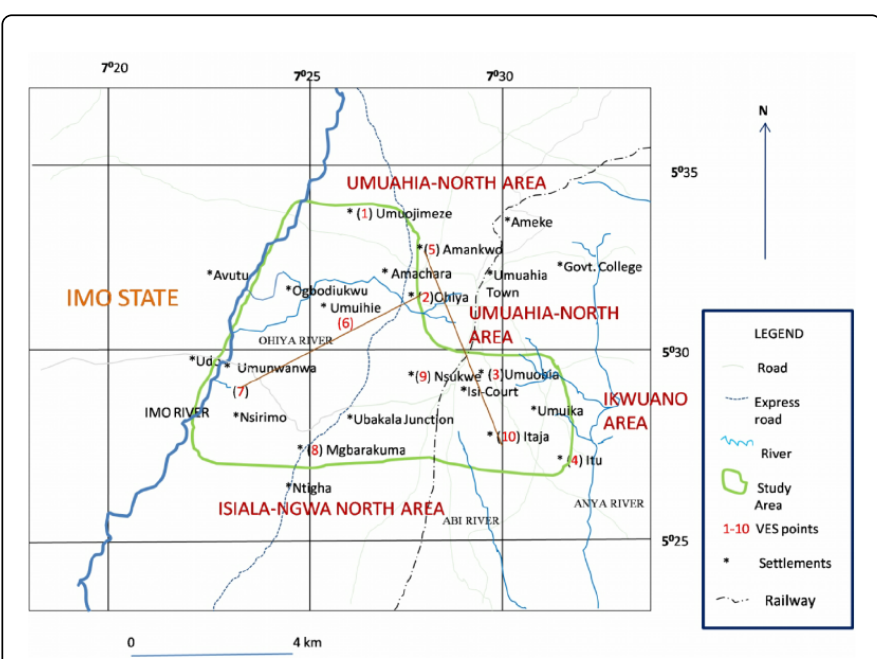

Figure 1: Study Area Umuahia.

In terms of methods the study adopted the ex-post-facto research design. Data for temperature parameters (maximum and minimum temperatures) were collected from the archive of the Nigerian meteorological agency (Abuja) for the period 1986-2015. On the other hand large scale predictor's data were collected from the archive of HadCM3 (Table 1).

\begin{tabular}{|l|l|l|l|}
\hline Predictor & $\begin{array}{l}\text { SDSM } \\
\text { code }\end{array}$ & Predictor & $\begin{array}{l}\text { SDSM } \\
\text { code }\end{array}$ \\
\hline Mean sea level pressure & MSLP & Surface airflow & P_f \\
\hline Surface zonal airflow & P_U & Surface meridional velocity & P_v \\
\hline Surface vortices & P_z & Surface wind direction & p-th \\
\hline Surface divergence & P_zh & 500-hpa air flow strength & P5_f \\
\hline 500-hpa zonal velocity & P5-U & 500-hpa meridional & P5_v \\
\hline 500-hpa vortices & P5_Z & 500-hpa geopotential height & P500 \\
\hline 500-hpa wind direction & P5th & 500-hpa divergence & P5zh \\
\hline 850-hpa airflow strength & P8_f & 850-hpa zonal velocity & P8_U \\
\hline 850 meridional velocity & P8_v & 850-hpa vortices & P8-z \\
\hline 850 geopotential height & P850 & 850-hpa wind direction & P8th \\
\hline 850-hpa divergence & P8zh & Relative humidity at 500-hpa & R500 \\
\hline $\begin{array}{l}\text { Relative humidity at } 850- \\
\text { hpa }\end{array}$ & r850 & $\begin{array}{l}\text { Near surface relative } \\
\text { humidity }\end{array}$ & rhum \\
\hline Surface specific humidity & Shum & Mean temperature at 2m & temp \\
\hline
\end{tabular}

Table 1: Large scale predictor's data were collected from the archive of HadCM3.
To identify the appropriate grid cell of the hadCM3 that corresponds to the area under investigation, the hadCM3 grid cell was super-imposed on the map of Niger-delta region and the area was picked out within the map. Niger delta region because, the HadCM3 resolution is too large $\left(412 \mathrm{~km}^{2}\right)$ for the area under review, as such trying to identify the grid cell corresponding to the area needs to incorporate adjoining areas to the study area (Abia). Therefore the grid 3, 31 of the HadCM3 GCM was selected. Having selected the grid cell, data for large scale predictors were downloaded from http:// www.cics.uvic.ca/scenarios/sdsm/select.cgi. However, analyses were done in two categories. This first was achieved via the downscaling techniques and in the environment of the SDSM and the second form of analysis was achieved via the analysis of variance (ANOVA) and Pearson's product moment correlations (PPMC) in the environment of the SPSS.

Conversely, the SDSM software operates in these itemized steps: quality control (this ensures that data are properly arranged and that they are complete as calibrated), predictors screening (this identifies the various predictors that would likely predict the predict and based on the $r$ value, partial $r$ value, and the $p$ value realized), model graduation or calibration (this step computes a MLR between the predictors and predict and also tells the proportion of influence in the predicted that can be explained by the predictors), weather generation (this regenerates the weather of the area by creating up to 20 ensembles or likelihood of occurrence in the predicted, graphing model out puts, statistical analysis, \& scenario generation (here the predictors of the Hadcm 3 is used to reproduce the weather element(s) of interest in area where the downscaling study is being carried out and in this case Umuahia metropolis). Generally, temperature is deemed continuous in their distribution, its uncertainty (minimum and maximum temperatures) were computed by comparing the monthly means of the observed data with those of the downscaled using the Wilcoxon signed rank test at $95 \%$ level of significance. This uncertainty analysis is necessitated because there was need to find out the ability of the calibrated model to type the real world scenario which also occurs in a dynamic manner. Having downscaled, the minimum and maximum temperatures of the area, ANOVA was then applied on the downscaled temperature to find out changes in the temperature characteristics using the epochs under consideration (1960-2080).

\section{Results and Discussion}

In Table 2, the predictors used for this study are presented and were found to be valid at $\mathrm{p}<0.05$. The result also showed that predictors valid for minimum and maximum temperatures downscaling in the area of study are; Mean sea level pressure (MSLP), Relative humidity at 500-hpa (r500), Relative humidity at 850-hpa (r850), and Temperature at 2 meters above sea level (temp). The chosen predictors in Table 2 also exhibit some physical association with the predict ands (minimum and maximum temperatures) and have been identified by Wilby et al, as basic predictors of temperature characteristics in the tropics and by extension have also been used by Mahmoud and Babel [13]. In similar studies with varying levels of success (Table 2).

During the model calibration three performance indices were used and include $\mathrm{P}$ value, Pr value, $\mathrm{R}$ value; and two indices were used for checking of model performance, that is, explained variance (EV) and the standard error (SE). Therefore the mean explained variance analyzed ranged between $63-76 \%$ and 65 and $83 \%$ for minimum and maximum temperatures respectively, while standard error fell between 0.8 and $1.25^{\circ} \mathrm{C}$ for both minimum and maximum temperatures 
respectively. This result showed consistency with that of previous related works (Souvignet \& Heinrich, 2011; Rashimd \& Mukand, (2014). In terms of validation, daily temperature data for the period 1992-2001 was generated by the SDSM and matched with observed minimum and maximum temperature for same period. Performance indicators for the validation were R2 values; root means square error (RMSE) and ratio of the standard deviation (Table 3).

\begin{tabular}{|l|l|l|l|l|}
\hline Predictors selected & $\begin{array}{l}\text { SDSM } \\
\text { Code }\end{array}$ & Predictand & $\begin{array}{l}\text { Correlation } \\
\text { coefficient }\end{array}$ & $\begin{array}{l}\text { Partial } \\
\text { correlation }\end{array}$ \\
\hline $\begin{array}{l}\text { Mean sea level } \\
\text { pressure }\end{array}$ & MSLP & $\begin{array}{l}\mathrm{T} \min \& \mathrm{~T} \\
\max \end{array}$ & $0.87 \& 0.73$ & $0.63 \& 0.61$ \\
\hline $\begin{array}{l}\text { Relative humidity at } \\
\text { 500-hpa }\end{array}$ & $\mathrm{r} 500$ & $\mathrm{~T} \max$ & 0.92 & 0.86 \\
\hline $\begin{array}{l}\text { Relative humidity at } \\
\text { 850-hpa }\end{array}$ & $\mathrm{r} 850$ & $\mathrm{~T} \max$ & 0.81 & 0.71 \\
\hline $\begin{array}{l}\text { Temperature at 2 } \\
\text { meters above sea } \\
\text { level }\end{array}$ & Temp & $\begin{array}{l}\mathrm{T} \min \& \mathrm{~T} \\
\max \end{array}$ & $0.88 \& 0.94$ & $0.74 \& 0.89$ \\
\hline
\end{tabular}

Table 2: Selected predictors for model calibration.

\begin{tabular}{|c|c|c|c|c|c|}
\hline Ncep/HadCM3 & $\begin{array}{l}R 2 T \max \& \\
T \text { min }\end{array}$ & $\begin{array}{l}\text { RMSE } \\
\text { max } \\
\text { Tmin }\end{array}$ & $\begin{array}{l}\mathbf{T} \\
\boldsymbol{\&}\end{array}$ & $\begin{array}{l}\text { Rs } T \text { max } \\
\& \mathrm{~T} \text { min }\end{array}$ & $\begin{array}{l}P \text { - Value at } \\
0.05 T \text { max, } \\
T \text { min }\end{array}$ \\
\hline Daily & $0.27 \& 0.21$ & $\begin{array}{l}4.35 \\
4.52\end{array}$ & \& & $1.00 \& 1.02$ & 0.000 .00 \\
\hline Monthly & $0.85 \& 0.70$ & $\begin{array}{l}2.14 \\
2.72\end{array}$ & \& & $0.88 \& 0.56$ & 0.000 .00 \\
\hline Seasonal & $0.52 \& 0.61$ & $\begin{array}{l}3.72 \\
3.58\end{array}$ & \& & $0.94 \& 0.87$ & 0.000 .00 \\
\hline \multicolumn{6}{|l|}{$A_{2}$ experiment } \\
\hline Daily & $0.26 \& 0.23$ & $\begin{array}{l}4.26 \\
4.56\end{array}$ & \& & $1.00 \& 1.02$ & 0.000 .00 \\
\hline Monthly & $0.72 \& 0.81$ & $\begin{array}{l}2.12 \\
1.94\end{array}$ & $\&$ & $0.92 \& 0.86$ & 0.000 .00 \\
\hline Seasonal & $0.51 \& 0.59$ & $\begin{array}{l}3.74 \\
3.59\end{array}$ & \& & $0.96 \& 0.98$ & 0.000 .00 \\
\hline
\end{tabular}

Table 3: Validation of the SDSM data (1991-2001).

The indicators in (Table 3 ) were computed by synthesizing NCEP \& $\mathrm{A}_{2}$ scenario predictor's data with predict and ( $\left.\mathrm{T} \min \& \mathrm{~T} \max \right)$. However, NCEP performance indicators derived, performed better than that of the $\mathrm{A}_{2}$ scenario experiment predictors, reason being that the model was calibrated from the NCEP predictors. Conversely the model performed better at the monthly sub model scale than at other periods of both seasonal and daily scales (Table 3). This finding is inconsistent with the finding of Babel and Mahmood (2014), whose models performed better at the daily sub model scale for temperature parameters investigated in their study. Adduced reason for this variability in model performance Levels include variation in the environments in which the studies were carried out (i.e. semi-arid \& tropical environments) (Table 4).

However, there exist some identified uncertainties in Table 4. In the table, NCEP predictors revealed some level of uncertainty for the month of December as the $\mathrm{P}$ value for that month is less than 0.05 . The same uncertainties are traceable to the $\mathrm{A}_{2}$ scenario for $\mathrm{T}$ max for the months of November and December respectively. However for T min, NCEP showed that there are little or no uncertainties between the modeled data mean and the observed data means for all months except for the month of March, which experiences the beginning of rainfall in the area and probably affected the simulation. However, in the $\mathrm{A}_{2}$ experiment for $\mathrm{T}$ min, December showed some uncertainty between modeled and observed data at $\mathrm{P}<0.05$ (Table 5).

\begin{tabular}{|l|l|l|l|l|}
\hline \multicolumn{3}{|l}{ Umuahia met station max temp } & \multicolumn{3}{l|}{$\begin{array}{l}\text { Umuahia met station } \\
\text { min temp }\end{array}$} \\
\hline Months of the year & NCEP & $\mathbf{A}_{2}$ & NCEP & $\mathbf{A}_{2}$ \\
\hline January & 0.543 & 0.143 & 0.111 & 0.343 \\
\hline February & 0.723 & 0.723 & 0.123 & 0.823 \\
\hline March & 0.543 & 0.243 & 0.058 & 0.443 \\
\hline April & 0.123 & 0.051 & 0.123 & 0.351 \\
\hline May & 0.343 & 0.803 & 0.343 & 0.903 \\
\hline June & 0.423 & 0.723 & 0.113 & 0.921 \\
\hline July & 0.543 & 0.543 & 0.543 & 0.513 \\
\hline August & 0.12 & 0.723 & 0.22 & 0.829 \\
\hline September & 0.443 & 0.543 & 0.143 & 0.663 \\
\hline October & 0.723 & 0.7 & 0.313 & 0.553 \\
\hline November & 0.523 & 0.053 & 0.123 & 0.663 \\
\hline December & 0.013 & 0.023 & 0.153 & 0.153 \\
\hline $\begin{array}{l}\text { P values at } 0.05 \text { level of significance of Wilcoxon Signed Rank test results for all } \\
\text { the months of the year for Observed and modeled data means. }\end{array}$ \\
\hline
\end{tabular}

Table 4: Uncertainty analysis for temperature downscaling in the study area.

\begin{tabular}{|l|l|l|l|l|l|}
\hline & $\begin{array}{l}\text { Sum of } \\
\text { Squares }\end{array}$ & Df & $\begin{array}{l}\text { Mean } \\
\text { Square }\end{array}$ & F & Sig. \\
\hline $\begin{array}{l}\text { Between } \\
\text { Groups }\end{array}$ & 499.661 & 3 & 166.554 & 284.141 & .000 \\
\hline Within Groups & 28308.9 & 43796 & 11.655 & & \\
\hline Total & 28808.56 & 43799 & & & \\
\hline
\end{tabular}

Table 5: Downscaled maximum temperature.

Furthermore, Table 5 explains the temporal variation in maximum temperature from downscale data for the area under investigation. It is evident from the table that there is a significant difference in temperature for the period 1960 and 2080. This finding is also valid at $\mathrm{p}<0.05$ (F, 227.1), however, the Duncan statistics in Table 4 revealed that the difference exists in three different categories and the first category is $1961-1990 \& 1991-2020$ with mean maximum temperature of $31.6^{\circ} \mathrm{Cand} 32.5^{\circ} \mathrm{C}$ respectively, while the other two categories are 2021-2050 and 2051-2080 with mean maximum temperature of $33.7^{\circ} \mathrm{C}$ and $34.2^{\circ} \mathrm{C}$ respectively (Table 6). 
Citation: Ozabor F, Nwagbara MO (2018) Identifying Climate Change Signals from Downscaled Temperature Data in Umuahia Metropolis, Abia State, Nigeria. J Climatol Weather Forecasting 6: 215. doi:10.4172/2332-2594.1000215

Page 4 of 5

\begin{tabular}{|l|l|l|l|l|}
\hline \multicolumn{5}{|c|}{ max_Asnr } \\
\cline { 1 - 3 } Duncana & \multirow{4}{*}{ Subset for alpha $=0.05$} \\
\cline { 3 - 5 } Identifier & N & $\mathbf{1}$ & $\mathbf{2}$ & $\mathbf{3}$ \\
\hline $1961-1990$ & 10950 & 31.6414 & & \\
\hline $1991-2020$ & 10950 & 32.5075 & & \\
\hline $2021-2050$ & 10950 & & 33.6456 & \\
\hline $2051-2080$ & 10950 & & & 34.2057 \\
\hline Sig. & & 0.317 & & 1.000 \\
\hline $\begin{array}{l}\text { Means for groups in homogeneous subsets are displayed. } \\
\text { a. Uses Harmonic Mean Sample Size }=10950.000 .\end{array}$ \\
\hline
\end{tabular}

Table 6: Duncan statistics for maximum temperature.

Indications are clear that temperature in the area has continued to rise since 1960 and will continue to rise even till 2080 (Figure 2), and by extension indicates climate change (Tables 7 and 8 ).

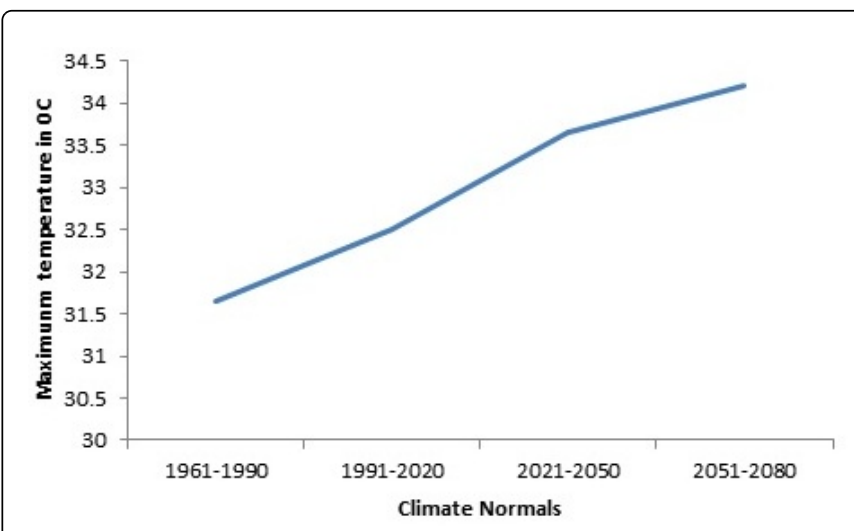

Figure 2: Maximum temperature trend of Umuahia.

\begin{tabular}{|l|l|l|l|l|l|}
\hline & $\begin{array}{l}\text { Sum of } \\
\text { Squares }\end{array}$ & Df & $\begin{array}{l}\text { Mean } \\
\text { Square }\end{array}$ & F & Sig. \\
\hline $\begin{array}{l}\text { Between } \\
\text { Groups }\end{array}$ & 499.661 & 3 & 166.554 & 284.141 & 0 \\
\hline Within Groups & 28308.9 & 43796 & 11.655 & & \\
\hline Total & 28808.56 & 43799 & & & \\
\hline
\end{tabular}

Table 7: Downscaled minimum temperature for Abia State.

Table 8 reveals that minimum temperature in the area is significantly different over time in the area. This statement is also valid at $\mathrm{P}<0.05$ (F, 284.1). Nevertheless, the Duncan post-hoc test in Table 8 shows that the mean temperature of the four epochs under investigation using downscaled data are significantly different from each other at $\mathrm{P}<0.05$. The indications are also clear that the areas minimum temperature has witnessed significant change of an upward trend (Figure 3). This also indicated that the temperature of the area has been and is still going to change if nothing is done to reduce GHGs emission in the area. Therefore adequate and well-structured action plans are required for reparations of the environment and by extension

the meteorological characteristics of the study area in particular and Nigeria in general.

\begin{tabular}{|l|l|l|l|l|l|}
\hline \multicolumn{5}{|c|}{ Subset for alpha = 0.05 } \\
\hline \multicolumn{7}{|l|}{ Duncan ${ }^{\mathrm{a}}$} & \multirow{5}{*}{ Identifiers } & N & $\mathbf{1}$ & $\mathbf{2}$ & $\mathbf{3}$ & $\mathbf{4}$ \\
\hline $1961-1990$ & 10950 & 23.0329 & & & \\
\hline $1991-2020$ & 10950 & & 23.8058 & & \\
\hline $2021-2050$ & 10950 & & & 24.686 & \\
\hline $2051-2080$ & 10950 & & & & 24.915 \\
\hline Sig. & & 1 & 1 & 1 & 1 \\
\hline $\begin{array}{l}\text { Means for groups in homogeneous subsets are displayed. } \\
\text { a. Uses Harmonic Mean Sample Size }=10950.000\end{array}$ \\
\hline
\end{tabular}

Table 8: Duncan statistics for minimum temperature.

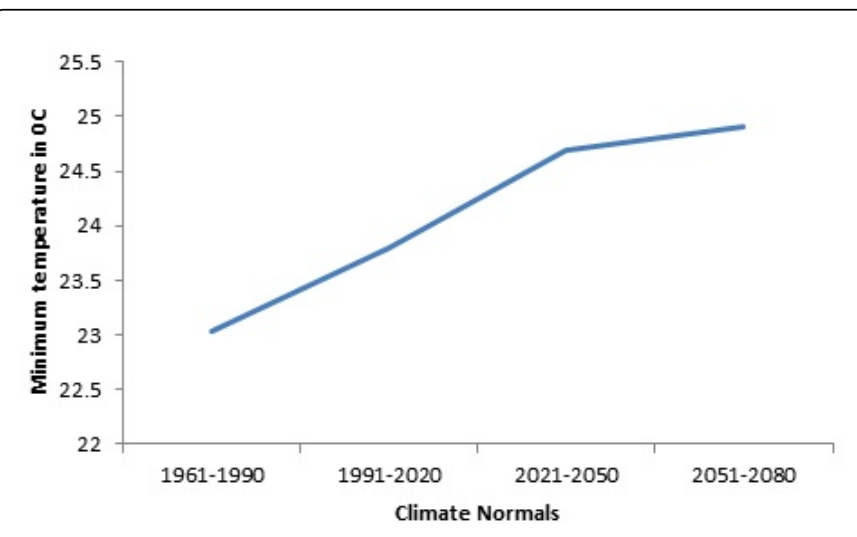

Figure 3: Minimum temperature trend of Umuahia.

\section{Conclusion and Recommendations}

In conclusion, evidence from downscaled data of Umuahia in Abia state indicates that temperature (minimum and maximum) have changed in the area. Nevertheless, the identified change is also attributed to assumptions and factors of climate change as advocated by HadGCM3 (which include but not restricted to, increased and uncontrolled urbanization, GHGS emissions proliferation, and increase population). However, the temporal patterns of temperature indicated that there are changes from normal to normal for current and future temperature patterns although with some uncertainties in the forecasts. This is probably already causing some severe environmental impacts and the fear is that if necessary palliative steps are not taken the environment may witness irreparable change. Nonetheless, the predicted changes in temperature pattern are seen to be continuously on the increase (although with some uncertainties), if anthropogenic conditions are sustained in the area.

However, the researchers having noted that the study adopted only one GCM data set, advices that the assertions of this study be utilized with caution, this is one limitation of the current study. A suggestion to 
this is that there is need to utilize more GCMs in the area for a more robust study and also to expand the study beyond the boundaries of the current study to account for the boundary conditions which may have not been captured in the current study, since the intension was to capture only the temporal information of the temperature characteristics and to find out how well the HadCM3 captured the climate information of the area. Also worthy of note is the expansion of predict ands, so that a more all-encompassing statement can be made about the climate situation in the study area and beyond in Nigeria. Therefore there is need to do the following:

- Assemble a working group that will work on the suggestions made above

- A synergy be established between Nigerian meteorological agency and the working group

- There is need to produce a localized GCM, which for now is not available

- Also there is need to carry out similar study across the other regions of Nigeria

- The state legislature is by this study, implored to review critically the existing laws on GHGs emission and other anthropogenic activities that exacerbate GHGs emission, for to improve on them and create stiffer sanctions for erring members of the polity.

\section{References}

1. Ayoade JO (2004) Introduction to Climatology for the Tropic. Spectrum Books, Ibadan.

2. Chen S, Shi Y, Guo Y (2010) Temporal and spatial variation of annual mean air temperature in arid and semiarid region in northwest China over a recent 46 year period. J Arid Land 2: 87-97.

3. Chen WH, Liu YX (2002) The seasonal characteristics of climatic change trend in China from 1951 to 1997. Plateau Meteorology 21: 251-257.

4. Cheng SL, Wang NA (2004) Study on air temperature change in Lanzhou City in recent 70 years. Arid Land Geography 27: 558-563.

5. Tu QP, Deng ZW, Zhou XL (2000) Study on regional feature of China temperature variation. Acta Meteorologica Sinica 58: 288-296.

6. Wang XJ, Fang ZF (2004) Surface air temperature in China and its relation to Arctic Oscillation Index. Plateau Meteorology 23: 80-88.

7. Wang Y, Li X, Miao QL (2004) Analyses on variety characteristics of temperature. AridLand Geography 27: 41-46.

8. XU GQ, Wei WS (2004) Climate change of Xinjiang and its impact on eco-environment. Arid Land Geography 27: 14-18.

9. Yuan YJ, Mu GJ (2004) Features of spring climate change in Tianshan Mountainous Area for the recent 40 years and comparison with that in plain area of Xinjiang. Arid Land Geography 27: 35-40.
10. Zuo HC, Lv S (2004) Variations trend of yearly mean air temperature and precipitation in China in the last 50 years. Plateau Meteorology 23: 238-244

11. Ayoade JO (2008) Techniques in Climatology. Stirling-Horden Publishers Ltd, Ibadan.

12. Karyn T, Williams JW (2010) Globally downscaled climate projections for assessing the conservation impacts of climate change. Ecol. Appl 20: 554-565.

13. Chu JT, Xia, J, Xu CY, Sigh VP (2010) Statistical downscaling of daily mean temperature, pan evaporation and precipitation for climate change scenarios in Haihe River, China. Theor. Appl. Climatol 99: 149-161.

14. Fujihara Y, Tanaka K, Watanabe T, Nagan T, Kojiri T (2008) Assessing the impacts of climate change on the water resources of the Seyhan River Basin in Turkey: use of dynamically downscaled data for hydrologic simulations. J. Hydrol 353: 33-48.

15. Hashmi MZ, Shamseldin AY, Melville BW (2011) Comparison of SDSM and LARS WG for simulation and downscaling of extreme precipitation events in a watershed. Stoch. Environ. Res. Risk Assess 25: 475-484.

16. Sahana Paul, CM Liu, JM Chen, SH Lin (2008) Development of a statistical downscaling model for projecting monthly rainfall over East Asia from a general circulation model output. J. Geophys. Res 113: art. no. D15117.

17. Wilby RL, Hay LE, Leavesley GH (1999) A comparison of downscaled and raw GCM output: implications for climate change scenarios in the San Juan River Basin. Colorado. J. Hydrol 225: 67-91.

18. Wilby RL, Dawson CW (2004) Using SDSM Version 3.1-A Decision Support Tool for the Assessment of Regional Climate Change Impacts. User Manual. United Nations Framework Convention on Climate Change, Bonn, Germany.

19. Karamouz M, Nazif S, Fallahi M (2010) Rainfall downscaling using statistical downscaling model and canonical correlation analysis: a case study. In: Palmer RN (editor), World Environmental and Water Resources Congress 2010: Challenges of Change Proceedings of the World Environmental and Water Resources Congress 2010. American Society of Civil Engineers, Reston, Va 4579-4587.

20. Teutschbein C, Wetterhall F, Seibert J (2011) Evaluation of different downscaling techniques for hydrological climate-change impact studies at the catchment scale. Clim. Dyn 37: 2087-2105.

21. Pervez Md S, Henebry GM (2014) Projections of the GangesBrahmaputra precipitation-Downscaled from GCM predictors. Journal of Hydrology 517: 120134.

22. Wilby RL (2005) Constructing wet season precipitation scenarios for a site in the Anti-Atlas Mountains, Morocco. Optimizing Land and Water Resources in Arid Environments, 14-18 March, Agadir, Morocco. 